\title{
Accounts and Accountability: Corruption, Human Rights, and Individual Accountability Norms
}

\author{
Hun Joon Kim and J.C. Sharman
}

\begin{abstract}
Two parallel norms mandate an international duty to hold state leaders individually accountable for serious corruption and human rights crimes. The development of these new norms is poorly explained by realist and neoliberal perspectives, but there are also weaknesses in recent constructivist explanations of norm diffusion that emphasize agency at the expense of structure. Such approaches have difficulty explaining the source of and similarities between new norms, and treat norm entrepreneurs as prior to and separate from their environment. In contrast, drawing on sociological institutionalism, we present a more structural explanation of individual accountability norms. The norms derive from an overarching modernist world culture privileging individual rights and responsibilities, as well as rational-legal authority. This culture is more generative of norm entrepreneurs than generated by them. The specific norms are instantiated through a process of "theorization" within permissive post-Cold War conditions, and diffused via mimicry, professionalization, and coercive isomorphism.
\end{abstract}

In spring 2011, Libya was convulsed by an uprising against the dictatorial rule of Muammar Qaddafi. Egregious human rights violations on the part of Qaddafi's regime not only provoked a NATO intervention but also moved the International Criminal Court (ICC) to indict Qaddafi, his son, and the head of security for war crimes. ${ }^{1}$ Yet the first blow against the regime was struck not by the United States, NATO, nor the UN, but a much less likely source: Switzerland. On 24 February 2011 Switzerland froze $\$ 630$ million of funds controlled by Qaddafi, his sons, and others within the "Brother Leader's" government. The Swiss government reasoned that Libyan public funds could otherwise be misappropriated by these individuals. This followed earlier action by Switzerland and other countries to freeze the assets of Zine el-Abidine Ben Ali, Hosni Mubarak, and both leaders' families and close

We gratefully acknowledge comments and suggestions from Michael Barnett, Luke Glanville, Seb Kaempf, TongFi Kim, Andrew O’Neil, Andrew Phillips, Kathryn Sikkink, Pat Weller, Wes Widmaier, two anonymous reviewers, and the editors. Kim gratefully acknowledges the financial support of Australian Research Council grant DE120101026 and the National Research Foundation of Korea grant NRF-2013S1A3A2055081, and Sharman acknowledges the support of Australian Research Council grants DP0986608 and DP0771521.

1. Marlise Simons, "Charges of War Crimes Brought Against Qaddafi," New York Times (Internet ed.), 27 June 2011. Available at <http://www.nytimes.com/2011/06/28/world/africa/28libya.html?_r=0>. Accessed 17 October 2011. 
associates after these regimes had fallen. ${ }^{2}$ Once more the justification was that these funds probably represented the proceeds of corruption. In Libya, Tunisia, and Egypt, there has been a strong international drive to hold leaders and other senior officials individually accountable both for their corruption and human rights crimes.

These events represent a notable parallel whereby the expectation of impunity previously enjoyed by state leaders guilty of major corruption and human rights crimes is now in the process of being replaced by very similar but separate norms of individual accountability. From Ferdinand Marcos to Augusto Pinochet to Charles Taylor to Qaddafi, most leaders who have repressed their populations have also engaged in major corruption offenses. The international response to each problem has evolved along parallel tracks, but the striking similarities between them have seldom been noted in either the scholarly or the policy literature. ${ }^{3}$

This article explains the rise and diffusion of international norms of individual accountability for leaders guilty of corruption and human rights crimes. Holding former or incumbent leaders individually accountable marks a significant change, challenging the very nature of sovereignty and sovereign immunity. Previously, dictators were free to abuse and steal from their own populations with no fear of international legal consequences. Currently they can be indicted and arrested outside their country for corruption and human rights offenses committed at home. They can also have their overseas wealth seized. Before 1990, only a handful of former heads of state had been indicted for such crimes, but since then sixty-seven heads of state from forty-three countries have been indicted. ${ }^{4}$ This new trend was bolstered by the institution of ad hoc criminal tribunals in Rwanda and the former Yugoslavia and the permanent ICC in 2002. Recently, international efforts have been mounted to recover assets stolen by the former rulers of the Philippines, Nigeria, Indonesia, Pakistan, Bangladesh, Ukraine, Peru, Nicaragua, Chile, Haiti, Taiwan, and Zambia as well as Tunisia, Egypt, and Libya. Regional agreements to combat corruption began to appear from the mid-1990s, while the United Nations Convention Against Corruption (UNCAC) dates from 2005. The move toward holding state leaders accountable for corruption and human rights transgressions has occurred within less than twenty years. ${ }^{5}$ It was unforeseen by many prominent scholars and policy-makers. ${ }^{6}$

We argue that individual accountability norms for both corruption and human rights crimes are derived from and embedded in an overarching culture of modernity that developed in the West but has spread around the world since 1945, and especially since decolonization and the end of the Cold War. In general, "modernity connotes

2. David D. Kirkpatrick, "As Protests Mount, Tunisia Delays Cabinet Reshuffle," New York Times (Internet ed.), 26 January 2011. Available at <http://www.nytimes.com/2011/01/27/world/africa/ 27tunisia.html>. Accessed 17 October 2011.

3. For rare exceptions, see Lutz and Reiger 2009; and Carranza 2008.

4. Lutz and Reiger 2009, 12.

5. See Roht-Arriaza 2005; and Bukovansky 2006.

6. See Hoffmann 1983, 22; Huntington 1987 and 1999, 228-31; and Kissinger 2001. 
the organization of society and the nation-state around universalized notions of progress and justice, as built up of rationalized organizations and associations, and as composed of autonomous, rational, and purposive individual citizens." this culture emphasizes individual rights and responsibility, and governance in line with impersonal, rational-legal authority where the public and private spheres are strictly separated. This overarching cultural structure constitutes actors and sets "boundary conditions" for their agency, notably in the composition of categories, problems, and solutions. ${ }^{8}$ Actors may diagnose problems from internal tensions between cultural tropes (for example, state sovereignty versus human rights), and in the way external developments are classified. Solutions are cause-and-effect stories or models that conform to, elaborate, and entrench specific features of world cultural tenets such as the parallel norms on individual accountability. Following Strang and Meyer, we refer to this process as "theorization." 9 The fact that two similar norms arose at the same time, without conscious coordination or emulation by the actors involved in each area, strongly suggests the primacy of contextual, structural factors over agency.

\section{Previous Explanations and Individual Accountability Norms}

\section{Neoliberal Institutionalism}

Neoliberal diffusion accounts have a difficult time explaining why more and more states and international organizations have passed laws and adopted treaties instituting individual accountability for both corruption and human rights crimes. As formalized in arrangements such as the ICC and the UNCAC, there is now an international duty for third-party states to hold leaders individually accountable. Rationalist scholarship on diffusion explains why the decisions of countries A and B affect those of country $\mathrm{C}$, either by changing incentives, or by changing available information. ${ }^{10}$ But human rights practices in countries $\mathrm{A}$ and $\mathrm{B}$ have little direct effect on country $\mathrm{C}$ - there are none of the externalities, market failures, or possibilities for joint gains from international cooperation. For scholars working within this tradition, norms emerge and diffuse in line with state interests according to deliberate costbenefit calculations. ${ }^{11}$ But even those of a rationalist orientation are likely to admit that the spread of international human rights law is more convincingly attributed to normative concerns rather than cooperation in the pursuit of mutual advantage. ${ }^{12}$

At first sight, the situation with corruption may be different. When it comes to anticorruption agreements such as the Organisation for Economic Cooperation and

7. Strang and Meyer 1993, 501.

8. Wendt 2003, 502.

9. Strang and Meyer 1993.

10. Dobbin, Simmons, and Garrett 2007.

11. Moravcsik 2000.

12. Simmons 2009, 123. 
Development (OECD) Anti-Bribery Convention, there is something approximating an iterated prisoner's dilemma that can be addressed according to the nowconventional remedies of the field. ${ }^{13}$ Yet it is not at all clear that kleptocracy fits the same template. There are no joint gains to be captured, or losses from opportunism to be feared, when the leaders of other states either refrain from or engage in embezzlement or bribery. Each country's behavior in this regard leaves its peers essentially unaffected. As with human rights, it is not clear why an international norm of individual accountability for kleptocracy offenses should have arisen on rationalist, functional grounds.

\section{Realism}

For realists, norms are mere epiphenomena that "reflect state calculations of selfinterest based primarily on the international distribution of power." 14 Realist accounts, however, cannot adequately explain why norms, which often stand in opposition to the interests of the strong, such as protecting human rights and attacking corruption, should have come into being. ${ }^{15}$ As norms of individual accountability are incorporated into domestic and international legal regimes, governments' freedom of action is significantly reduced. For democratic governments in particular, breaking international and domestic legal obligations may be difficult, embarrassing, or at least inconvenient.

It seems implausible to reduce regimes' countering of corruption and human rights abuses to tools of realpolitik. ${ }^{16}$ Although realpolitik may have favored leaving Pinochet unmolested during his trip to Britain in 1998, for example, he was nevertheless arrested. Similarly, US national interests favored allowing the Obiang family, rulers of Equatorial Guinea, Africa's third-largest oil producer and a significant US investment destination, to continue laundering the proceeds of corruption in the United States. Yet in October 2011 the US Department of Justice froze $\$ 71$ million of the Obiangs' wealth in real estate, a private jet, and Michael Jackson memorabilia with an eye to confiscating what are alleged to be the proceeds of corruption. ${ }^{17}$ (The Obiang government has an equally appalling record on human rights: the UN Human Rights Rapporteur noted, "They don't even hide the torture instruments. [They] were just on the table." ${ }^{18}$ ) Countries such as the United States and Britain have targeted kleptocrats' wealth despite actually benefiting from a

13. Axelrod 1984. Regarding corruption, see Abbott and Snidal 2002.

14. Mearsheimer 1994/1995, 339.

15. Reus-Smit 2004, 17.

16. McCoy and Heckel 2001.

17. Lee Ferran and Jason Ryan, "Smooth Criminal? DOJ Wants Michael Jackson's Glove from Dictator's Son," ABC News (Internet ed.), 25 October 2011. Available at <http://abcnews.go.com/Blotter/doj-seeksjackson-glove-dictators-son/story?id=14812081>. Accessed 17 October 2011.

18. Adam Nossiter, "US Engages with an Iron Leader in Equatorial Guinea," New York Times (Internet ed.), 30 May 2011. Available at <http://www.nytimes.com/2011/05/31/world/africa/31 guinea.html?pagewanted=all $>$. Accessed 17 October 2011 . 
laissez-faire view of grand corruption, given that their banks are most likely to profit from hosting stolen funds. ${ }^{19}$

\section{Constructivism}

Given the lack of fit between neoliberal and realist logics and the norms of individual accountability, constructivism might seem to provide a better explanation. Norm diffusion has been a central focus in constructivist research. Many studies have examined the spread of human rights norms, though much less attention has been devoted to corruption issues. ${ }^{20}$ In this study we focus on the most widely employed constructivist account of norm diffusion, the norm life cycle, ${ }^{21}$ which brings into sharp relief several key divides in constructivist scholarship, especially relating to the agentstructure debate. International norms are said to arise in three phases: emergence, cascade, and internalization. A central element of this framework is the tipping point, which distinguishes the emergence phase from the diffusion phase. Norms spread slowly in the earlier phase, mainly through persuasion by norm entrepreneurs, but then diffuse rapidly after the tipping point. The role of norm entrepreneurs and pressure from like-minded states is central. The final stage is when the norm is taken for granted and produces rule-consistent behavior.

Finnemore and Sikkink's norm life cycle theory has been the most influential theoretical framework in empirical constructivist research. Their original paper is the most cited constructivist article. ${ }^{22}$ Activists Beyond Borders and The Power of Human Rights further elaborate this thesis; the former is the single most cited constructivist work of any kind ever. ${ }^{23}$ More recently, The Justice Cascade further explores the origins, diffusion, and effect of domestic and international human rights prosecutions. Although the norm life cycle theory is not the only constructivist account of this phenomenon, it provides a fundamental frame of reference for current constructivist research. ${ }^{24}$

19. Author's interview with Global Witness officials, London, 7 September 2011; and author's interview with World Bank officials, Washington, DC, 22 March 2011.

20. For exceptions, see McCoy and Heckel 2001; Bukovansky 2006; and Larmour 2006.

21. Finnemore and Sikkink 1998.

22. See <http://journals.cambridge.org/action/displayJournal?jid=INO\&tab=mostcited-tab $>$. Accessed 28 August 2012.

23. According to Google Scholar (accessed 28 August 2012), Activists Beyond Borders has been cited 6,257 times, compared with 3,909 for Wendt's Social Theory of International Politics or 5,930 for After Hegemony, Keohane's most cited work.

24. Given the number of scholars working in this vein, evidence here must necessarily be selective rather than exhaustive. Risse's work on the logic of arguing certainly prioritizes actors such as domestic and transnational advocacy networks. Risse 2000, 29. Clark finds a "critical role" of Amnesty International in the development of international legal norms on torture, disappearance, and extrajudicial execution. Clark 2001, 11. Bob, although introducing important questions of why some norms become more prominent than others, focuses his explanation on "the strategic action by local-level human rights victims." Bob 2002, 134. Thomas's work on the end of the Cold War concludes that the causal effect of ideas and norms "depends on political agency." Thomas 2005, 139. Kelley's recent study of the international election 
In particular, it highlights three key divides within constructivist scholarship. First, in response to constructivists' tendency to counterpose the logic of consequences to the logic of appropriateness, this account speaks of "strategic social construction," through which actors are making means-ends calculations to change the cultural structure. ${ }^{25}$ Although not every constructivist accepts a complementary relationship between rationalism and constructivism, ${ }^{26}$ many scholars now agree that the relationship need not be mutually exclusive. ${ }^{27}$ Second, state centrism has been another focus of debate in constructivism, especially in response to Wendt's Social Theory of International Politics, which portrays states as agents. ${ }^{28}$ Although not explicitly addressing this divide, the norm life cycle moves away from state centrism by stressing norm entrepreneurs, nongovernmental organizations (NGOs), international organizations, and professions, as well as states. Third, the relative importance between ideational and material power has also been a central focus of constructivist debate. ${ }^{29}$ The norm life cycle account cautiously claims an independent causal role for ideas with some reservation, represented by "world time-context" according to which ideas associated with the losing side of the global war or economic failure are at risk of being discredited. ${ }^{30}$

Scholars have identified many other important divides in constructivism, spawning a multitude of "constructivisms with adjectives": positivist (modern) versus postpositivist (postmodern or critical), liberal versus nonliberal, scholars stressing global norms (systemic) versus local effects (unit-level), and those viewing international system as anarchy versus authority. That constructivism has reached a point of theoretical fragmentation is significant in itself. We revisit "the most salient and sustained" divides in constructivism - the agent-structure debate. ${ }^{31}$ In principle, virtually every constructivist agrees on the mutual constitution of agents and structure. However, in practice, the agent-structure debate remains highly contested.

\section{Agentic and Structural Explanations}

Ignited by Wendt's 1987 seminal article, the agent-structure debate within International Relations has more often taken place at the level of meta-theory than

monitoring norm is based on the norm life cycle theory. Kelley 2008. Acharya, despite introducing important "localization" processes, still puts a greater emphasis on "local agents." Acharya 2004. In addition, writing on the eastward expansion of the EU, Schimmelfennig argues for the centrality of rhetorical action: "the strategic use of norm-based action." Schimmelfennig 2001, 48. Even Bukovansky's work, which parallels our treatment of world culture in many respects, holds that constructivists "need to pay more explicit attention to the instrumental use of ideas." Bukovansky 2002, 38.

25. Finnemore and Sikkink 1998, 910.

26. Reus-Smit 2009, 227.

27. Hurd 2008, 310.

28. Wendt 1999.

29. Reus-Smit 2009, 220.

30. Finnemore and Sikkink 1998, 909.

31. See Adler 2002, 104; and Hurd 2008, 303-4. 
empirically oriented theory. ${ }^{32} \mathrm{We}$ address this question in linked theoretical and empirical discussion to make the topic more manageable and consider the relative strengths and weaknesses of theories that place more emphasis on agency versus those that favor structure. Two recent developments in constructivist scholarship provide a timely environment to bring the agent-structure debate back in.

First, Sikkink argued for the need to reconsider the agency-structure debate in explicitly criticizing "structural constructivism," based on taken-for-granted logics of appropriateness, for being unable to account for major, rapid political change. ${ }^{33}$ Instead, she argues for an "agentic constructivism" that focuses on norm entrepreneurs, especially NGOs, as well as crusading minor states, whose agency and activism promotes norms. In her 2011 keynote address to the Millennium Annual Conference, she further maintains, "too much attention has been lavished on the structural side of the equation, and far too little on the agency side." 34 She then applies this agentic label to empirical and theoretical work by scholars such as Price, Finnemore, Barnett, Risse, Reus-Smit, Pouliot, Wiener, Lynch, Towns, and Klotz. This move is an important departure from Wendt's position that the two most valuable contributions of constructivism are a stress on ideas and a focus on structure. ${ }^{35}$ Contradicting this view of neglected agency, Finnemore and Sikkink's 2001 review of constructivism actually observed that "most of the foregoing mechanisms for social construction explore the agentic side of this mutual constitution process." ${ }^{36}$ We see little change in this agentic orientation over the intervening decade. Dobbin, Simmons, and Garrett note in 2007, "more recently, constructivist studies highlight how international agencies and governments actively construct theories of action and corresponding models of behavior." 37

Second, recent efforts to resolve the classical agent-structure debate have adopted a relational approach, or stipulated missing links between agent and structure. The first calls for a move away from "substantialism," that is, treating agency and structure primitives, and proposes "relationalism," emphasizing processes. ${ }^{38}$ This emphasis on process recently takes an empirical turn in the work on "practice," 39 "narrative," 40 and "networks." 41 Thus, there is a resurgent interest in the empirical implications of the agent-structure problem in International Relations to which our study contributes by focusing on norm diffusion.

32. Adler 2002, 106.

33. Sikkink 2011a, 235-37.

34. Sikkink 2011b, 2-4, 7.

35. Wendt maintains constructivism can be summarized as "structural idealism" and that "constructivists are structuralists." See Wendt 1999, 1; and 1995, 72.

36. Finnemore and Sikkink 2001, 403.

37. Dobbin, Simmons, and Garrett 2007, 452.

38. Jackson and Nexon 1999.

39. See Doty 1997; and Adler and Pouliot 2011.

40. Suganami 1999.

41. Goddard 2009. 
Before reviewing the relative strengths and weaknesses of different versions of constructivism with a more structural bent versus those favoring agency, it is important to clarify what we are not arguing. Not every constructivist now emphasizes agency over structure, ${ }^{42}$ nor is constructivism some monolithic body of ideas, nor have agentic explanations completely eliminated structure from their accounts, nor is incorporating some role for agency in constructivist explanations somehow "selling out." Debate is not advanced by caricature. It bears repeating that the varying weights placed on agency and structure are differences of degree, not absolutes. As Suganami shrewdly observes, "'agent-explanations' may always already be partly 'structure-explanations,' and vice versa."43

Although he also gives prominent billing to agency, Wendt argues that there are three reasons for favoring structural explanations. ${ }^{44}$ First, because the rest of the field has so little to say about structure, work in this vein marks a distinctive and valuable contribution. Constructivism is structural, not because it has no role for agency, but because relative to dominant choice-theoretic approaches it has much more to say about structure. Second, structural theories have an important advantage over individualist accounts of allowing "multiple realizability," where different combinations of actions and interactions could result in the same outcome. Third, Wendt refers to a "high explanatory rate of return," because knowing about the structure should enable us to explain and perhaps even predict patterns in actors' behavior, even if we know little about the particular actors.

Structural explanations are not deterministic. Waltz specifies that "structures shape and shove; they do not determine the actions of states." ${ }^{25} \mathrm{He}$ claims that there is a strong tendency for states to engage in balancing, but not all states are balancing all the time. Incorporating a cultural view of structure does not change this because "culture guides action but does not determine it." ${ }^{46}$ However, this cultural indeterminacy does not mean that "anything goes." The culture of modernity, for example, is much more compatible with liberal democracy, communism, or technocratic authoritarianism than theocracy or dynastic monarchy. ${ }^{47}$ As a structural theory, sociological institutionalism makes a stochastic argument, where the culture of modernity shapes actors and outcomes but does not determine them.

A common criticism of structural theories is that they better explain stasis and continuity than change. ${ }^{48}$ This approach is also less effective in explaining which of many possible potential norms, all congruent with the cultural structure, will arise and diffuse, as well as the timing of norm adoption. ${ }^{49}$ Finnemore, who first

42. See, for example, Barnett 2009; Bukovansky 2002; Reus-Smit 1999; and Wendt 1999.

43. Suganami 1999, 378.

44. Wendt 1999, 152-54, 184.

45. Waltz 2000, 24.

46. Barnett and Finnemore 2004, 19.

47. Bukovansky 2002, 8-9.

48. Sikkink 2011b, 5.

49. Finnemore and Sikkink 1998, 907. 
introduced sociological institutionalism to constructivism, took issue with the theory's inattention to mechanisms of change in the cultural structure itself. ${ }^{50}$ These weaknesses are said to illustrate the need for a larger dose of agency, as represented in the norm life cycle. ${ }^{51}$ These scholars have foregrounded agents, especially norm entrepreneurs, intentionally and deliberately acting to create new norms. Often through case studies of a single norm, agentic theories can provide nuanced explanations of why specific norms arise and of their adoption's timing. In this manner, this approach addresses the weaknesses of earlier structural accounts. By emphasizing the significance of individual norm entrepreneurs to effect positive political change, agentic theories also potentially narrow the gap between research and practice in International Relations. ${ }^{52}$

Despite these positive contributions, there are trade-offs to be made by constructivist research programs that privilege agency, either as a deliberate conceptual move, or a pragmatic question of emphasis. When it comes to explaining norm diffusion, agentic theory has difficulty explaining the source of new norms and why audiences buy what norm entrepreneurs are selling, leaves the key notion of tipping points undertheorized, and treats norm entrepreneurs as prior to and separate from their environment. Ideational and normative structures are often treated only as the dependent variable in this type of research, not as a constant environmental factor that both constitutes the agents and shapes their interactions and decisions.

Given that all sides agree on the need for reconciling structure and agency concerns in explaining world politics, how might this best be achieved? A more complete empirical account of norm diffusion begins with structure and then incorporates agency, in contrast to norm life cycle accounts and related agentic theories. Pierson provides a helpful starting point for why a better story can be told from the structural side. ${ }^{53} \mathrm{He}$ begins by observing that most important social processes take a long time, yet social scientists are increasingly fixated on the short term, especially when hunting for causes. He further notes that short-term explanations tend to favor agency, whereas those incorporating the longer view tend to place a greater weight on structure. This conclusion maps on to the differences between sociological institutionalism and agentic constructivist arguments quite well. The former concentrates on deep, macro, long-term factors in making structural arguments, whereas the latter is focused on short-term, proximate causes and agency. Long-term processes may lead to sudden or short outcomes. Pierson explains collective action premised on long, slow structural developments that are catalyzed by contingent events, or conjunctions of such events. For example, McAdam accounts for the outbreak of the black civil rights movement in terms of slow-moving patterns of economic development and migration, catalyzed by proximate and contingent

50. Finnemore 1996, 339.

51. However, this is often referred to as "the macro-micro-macro model of social explanation," which suffers from "a built-in bias in favor of individual action (or agency)." Mayntz 2004, 248-50.

52. Sikkink 2011b, 2.

53. Pierson 2003. 
events such as the 1954 Supreme Court decision declaring racially segregated schools unconstitutional. ${ }^{54}$

These kinds of structural explanations do not exclude agency, but most of the explanatory work is done by development of progressive structural evolution, often catalyzed and facilitated by contingencies and exogenous shocks. ${ }^{55}$ Analogously, we incorporate some measure of agency within our predominantly structural explanation of the rise of individual accountability norms: long-term, macro-cultural trends constitute individual rights and rationalized impersonal authority; then the bounded exercise of agency in theorization instantiates these norms within the permissive context of the end of the Cold War.

\section{Sociological Institutionalism: Structure and Process}

Sociological institutionalism and constructivism have important things in common. Finnemore's early work draws on sociological institutionalism, and her collaborative work with Barnett on the bureaucratic pathologies of international organizations stresses the importance of the culture of modernity, as does Barnett's more recent work. ${ }^{56}$ Sociological institutionalism helped to inspire the constructivist research program, but the two have increasingly grown apart.

Scholarship within the sociological institutionalist tradition bears a strong family resemblance, being defined by a number of common, though not universal, premises. Chief among these is that formal organizational structures and action reflect legitimacy concerns at least as much as technical, functional requirements, or anything approximating a rational maximizing decision process. ${ }^{57}$ Sociologists attribute striking similarities (isomorphism) in organizations from the firm to the state and much else besides to conformity driven by a search for legitimacy, largely independent of functional organizational performance. ${ }^{58}$ Crucial for our argument, deep cultural changes are said to have valorized bureaucratic rationality, a means-end logic, and individual rights as the correct way of designing institutions, defining goals and aspirations, and undertaking action: "World-cultural forces for expansion and change are incorporated in people and organizations as constructed and legitimated actors filling roles as agents of great collective goods, universal laws, and broad meaning systems, even though the actors themselves interpret their action as self-interested rationality." 59

Modern organizations are said to be in thrall to myths and rituals. ${ }^{60}$ Institutions and actors are a product of the modern cultural environment. Where goals and measures

54. McAdam 1982. Also see Wendt 2005, 591, for the same example.

55. Barnett 2005, 164.

56. See Finnemore 1996; Barnett and Finnemore 2004; and Barnett 2009.

57. Hall and Taylor 1996, 949.

58. See Powell and DiMaggio 1991; and Drori, Meyer, and Hwang 2006.

59. Meyer et al. 1997, 157.

60. Meyer and Rowan 1977. 
of success are uncertain, organizations ritualistically mimic those of their peers conceived as being the most innovative and successful. A further force for convergence is where a community of self-styled experts — a profession — arises, solicits and receives mutual and external recognition, and sets about defining models of correct practice to be followed. ${ }^{61}$ Coercion may provide a supplementary mechanism for isomorphism, but it is power of the most indirect and structural kind, often a type of unconscious peer pressure, comparison, or rating. Individual behavior is more likely to follow the logic of appropriateness, according to which action is premised on identity, interpretation, and willful role playing, rather than rational maximizing. ${ }^{62}$

Despite this common orientation, however, there are some secondary differences within this tradition. Although Meyer and other proponents of the "world society" literature stress the ongoing, ineluctable process of global homogenization through rationalization, ${ }^{63}$ March and Olsen see continuing diversity as the stickiness of diverse institutional environments that ensures persistent variation. ${ }^{64}$ Powell and DiMaggio urge more attention to power and coercion in promoting isomorphism, whereas world society scholars give these elements less play. ${ }^{65}$ World society leaves little room for agency, ${ }^{66}$ whereas others allow a somewhat greater role for meaningful decisions. ${ }^{67} \mathrm{We}$ adopt a middle-of-the-road version of sociological institutionalism premised on the importance of the world society, but leaving some role for agency.

\section{Structure: The Culture of Modernity}

The starting point for sociological institutionalism is the culture of modernity, which privileges rationality, agency, and individual rights. ${ }^{68}$ This culture promotes the idea that individuals are purposive entities largely responsible for their own actions and fates. Sociological institutionalists are primarily interested in the post-1945 period, but they ground their foundational idea of the historical development of modernity and rationalization on Weber and Durkheim, among others. Sociological institutionalists begin with the idea of a gradual trend of secularization in Europe: "the Western cultural framework reflects the development, expansion, and secularization of the principally religious models of Western Christendom, a sustained cultural evolution extending into the human rights movements of the contemporary period." 69 According to this evolution, shared beliefs about the locus of agency were

61. Powell and DiMaggio 1991.

62. March and Olsen 1989.

63. See Meyer et al. 1997; and Drori and Krucken 2009.

64. March and Olsen 1998.

65. Drori and Krucken 2009, 16.

66. Meyer and Jepperson 2000.

67. March and Olsen 1989.

68. Strang and Meyer 1993.

69. Meyer and Jepperson 2000, 4. 
progressively relocated from God to the state, organizations, and individuals. Nature came to be regarded as more lawful and more amenable to scientific knowledge and human control. The ability to shape the social world came with a duty to advance justice and progress. Especially important is the Weberian idea of rationalization: "the structuring of everyday life within standardized impersonal rules that constitute social organizations as a means to a collective purpose." 70

The resulting culture of modernity is complex, abstract, and underspecified in terms of specific prompts for action. Initially limited to Europe and then North America, after 1945 and with decolonization and the fall of communism the culture of modernity diffused globally to become world culture. The culture of modernity's development was neither a smooth nor even process. In his analysis of civilizations, Katzenstein observes "internal pluralism and the coexistence of plural civilizations." ${ }^{\text {71 }}$ Following Eisenstadt's notion of multiple modernities, Katzenstein sees the significant influence of different religious traditions hindering the development of one global civilization. However, even for Eisenstadt, the existence of multiple modernities does not preclude the existence of one global civilization of modernity. ${ }^{72}$

In the study of International Relations, both constructivist and English School scholars stress this broad idea of a cultural complex specific to the modern era. For example, Bukovansky notes the fundamental shift to Enlightenment culture. According to this cultural structure and the more specific rules and norms that derive from it, rulers' rightful authority derives from the people rather than divine sanction, and the associated values of "equality, individual rights, [and] the power of reason to resolve political and administrative issues" are paramount. ${ }^{73}$ Making a similar argument from an English School perspective, Clark also notes the development of a distinctively modern culture of "individualism, rights and social contract." 74 International legitimacy relates to rightful membership of and rightful conduct in world society, and is instantiated in more specific norms and practices. ${ }^{75}$ Scholars also commonly see a geographic expansion and deepening of this distinctive culture, especially in the twentieth century, and even more so after the end of the Cold War. ${ }^{76}$

Agentic explanations do intermittently refer to broader cultural contexts, but seldom accord them a significant role in their explanations. Keck and Sikkink hold that "new ideas are more likely to be influential if they fit well with existing ideas and ideologies in a particular historical setting." 77 Finnemore and Sikkink, in

70. Meyer et al. 1997, 11.

71. Katzenstein 2010, 2, 17.

72. Ibid., 23.

73. Bukovansky 2002, 4. For similar constructivist arguments, see Reus-Smit 1999; and Philpott 2001.

74. Clark 2005, 86.

75. Clark 2007.

76. See Bukovansky 2002, 17; Reus-Smit 2011, 207; Philpott 2001, 11; and Clark 2005, 174.

77. Keck and Sikkink 1998, 204. 
explaining which norms matter, introduce the importance of the "intrinsic characteristics of the norm."78 It is usually those imbued with a "liberal identity," "democratic," "enlightened and civilized," or "like-minded" agents who drive norm diffusion. ${ }^{79}$ Price's concept of grafting a new norm onto existing norms has spurred more recent theoretical developments. ${ }^{80}$ Yet in each case, the cultural structure beyond agents tends to be relegated or bracketed, deployed only intermittently rather than as part of a theoretically coherent framework.

In terms of the relationship between actors and their ideational environment, agentic explanation tends to take a causal view according to which actors are temporally prior to and analytically separate from the norms they are said to create, whereas structural explanation treats actors as constituted by their cultural environment. This is a fundamental difference: a constitutive relationship means that actors are made possible by structures, whereas for causation it is a matter of "a contingent connection between independently existing entities." 81 Thus for agentic explanations, NGOs, epistemic communities, and transnational civil society (and their strategies) are held to be ontologically prior to the cultural environment. Agents engage in voluntaristic, purposeful, and intentional action to cause deliberate normative change. ${ }^{82}$ The explanatory approach is to see a new norm and ask "who caused this change?" However, there is less attention to the question of where and how the norm entrepreneurs come by their ideas in the first place.

For sociological institutionalists, the general notion of human rights, individual responsibility, and rational authority are key features of a general culture of modernity, and are prior to individual agents. Although individual norm adoptions have in part reflected contingent conjunctions, the fundamental impetus for emergence and diffusion has been the expansion of the culture of modernity, which cannot be reduced to individual agents. As Barnett puts it, "principled actors are creatures of the world they want to transform." 83 Rather than ignoring the role of NGOs, international organizations and transnational policy communities, however, a sociological institutionalist perspective sees them as crucial to a process of theorizing problems and solutions.

\section{Process: Theorization}

How does this particular structure, the culture of modernity, give rise to political change? The structure provided the conditions of possibility, indeed probability, for the norms to arise, in that the culture of modernity emphasizes individual rights

78. Finemore and Sikkink 1998, 906.

79. See Risse, Ropp, and Sikkink 1999, 9; and Hawkins 2004, 785.

80. Price 1998, 628. See, for example, Hawkins 2004; Acharya 2004; Carpenter 2007; and Kelley 2008.

81. Wendt 1995, 72 .

82. For recent examples, see Acharya 2004; Carpenter 2007; and Kelley 2008.

83. Barnett 2009, 621. 
and responsibilities, and rationalized government according to impersonal rules. However, as critics of structural theories have noted, by itself such an account is underspecified, and says little about timing. Given that there are many related norms consistent with the overarching cultural milieu, why specifically these parallel norms of individual accountability? Furthermore, given that the culture of modernity had been in place for decades, why did these norms arise in the 1990s and not earlier?

Sociological institutionalism interprets change as a process of organizations seeking to enhance their legitimacy by more closely approximating the idealized models that the cultural environment suggests. Since the modern environment stresses the agency of the individual, human rights, and Weberian rationalized governance, ${ }^{84}$ there has been an escalating process of diffusion of institutional forms and discourse aiming to achieve a more complete and encompassing realization of these ambitions, irrespective of their unreality. The decoupling of the ever-more idealized models from practice creates an expanding menu of problems, often exposed or exacerbated by exogenous shocks. New rights are created while the old ones are still routinely violated. Governments commit to new duties while their existing ones remain unfulfilled. The culture mandates that responsible agents must "do something" about it.

In response, agents theorize, which is to say they engage in a "self-conscious development and specification of abstract categories and the formulation of patterned relationships such as chains of cause and effect." 85 Theorization is the proximate, culturally mediated process of defining categories, problems, and solutions. Theorization relies on actors having significant, though bounded, agency. Theorizing actors have agency both in terms of intentionality and power, ${ }^{86}$ in that their choices may affect which of several compatible norms emerge, and when. These choices and actions produce intellectual results ranging from "simple concepts and typologies to highly abstract, complex, and rich models." ${ }^{87}$ Scientists, policy analysts, and professionals in particular are often understood as "culturally legitimate theorists," who "not only construct models but are able to promote them vigorously." 88

These actors attempt to persuade audiences by locating their ideas within the broader normative framework. ${ }^{89}$ Agents enact, elaborate, and specify particular aspects of the culture of modernity as they generate categories and cause-effect stories. The process of theorization constructs "forms of similarity within culturally recognized categories" of actors who share similar problems. ${ }^{90}$ Commonly used categories in diffusion research, such as "liberal identity," "enlightened and civilized," or "like-minded" agents, are not something given or a priori-they have been

84. See Drori, Meyer, and Hwang 2006, 11; Reus-Smit 1999; and Clark 2005.

85. Strang and Meyer 1993, 492. See also Tolbert and Zucker 1996; and della Porta and Tarrow 2012.

86. Wendt 2005, 591.

87. Strang and Meyer 1993, 493.

88. Ibid., 494-95.

89. della Porta and Tarrow 2012, 119.

90. See Strang and Meyer 1993, 495; and Tolbert and Zucker 1996, 193. 
theorized. Aside from composing categories, agents derive generic problems from the broader milieu and compose generic solutions derived from the same milieu..$^{91}$ Theorizing a problem creates the impetus for change, whereas theorizing a solution provides the concrete direction and nature of change. Generating categories, problems, and solutions is an interactive process, in that categories are often created by actors on the basis of purportedly shared problems that are argued to require the same solution. The generic character of each is important-following rationalized, universalizing cultural prompts, theorization is deliberately aimed at applying modular, universalistic solutions to a class of actors and problems, not idiosyncratic one-off instances.

Different actors will sometimes produce contrasting theories for similar issues, but the situation whereby uncoordinated actors independently hit upon common theorizations is at least as marked. Actors draw their ideas from and seek to align them with a common cultural structure that constitutes these actors. Additionally, the cultural structure favors theorizations that are more congruent with the culture of modernity while tending to winnow out those that are further removed. As one particular theorization becomes more widely diffused it will become more generic, and hence less reflective of local circumstances. Thus new norms are derived from world culture, but more immediately result from the conjunction of agents' parallel theorizations as shaped by the environment. They are thus products of human agency but less so of human design. ${ }^{92}$

Theorization provides the "missing link" between structural conditions of probability and the development of derivative, specific norms. This concept thereby addresses the problem of underspecification leveled at structural explanations, and does so in a nondeterministic fashion. But how, then, does this view of theorization fit with the structural cast of the overall explanation of individual accountability norms, and the more general discussion of agency and structure in constructivism we summarized earlier? Similar to the concepts other constructivists have deployed, such as practice, narrative and networks, theorization is a relational concept that mediates structure and agency. Thus, our explanation remains firmly premised on holism, ${ }^{93}$ which does not preclude a role for agency: "The emphasis on holism does not deny agency but instead recognizes that agents have some autonomy and their interactions help to construct, reproduce, and transform those structures." 94

Structure shapes theorization more than vice versa. This is because structure sets the general direction of normative change, whereas theorization sets the specific

91. Tolbert and Zucker 1996, 183.

92. March and Olsen 1998, 948.

93. Wendt 1999, 26. Similarly, George and Bennett argue, "if all individuals behave the same in the same social structure, then the interesting causal and explanatory action is at the level of the social structure, even if it must operate through the perceptions and calculations of individuals." George and Bennett 2005, $141-42$.

94. Barnett 2005, 163. 
instance; because structure is temporally and ontologically prior to theorization; and because structure delimits the possible range of successful theorizations. Although actors remain "knowledgeable, reflexive, and capable of learning" 95 for us as for Wendt, "cultural selection does most of the explanatory work." 96 Actors exhibit agency within relatively narrow confines, as the environment sets "the lenses through which actors view the world and the very categories of structure, action and thought." ${ }^{97}$ This cultural structure shapes and shoves the theorization process by constituting and privileging certain actors, making some form of theorizing more likely than others, and winnowing down alternatives. The structure constitutes "boundary conditions" that "select" for theorizations consistent with these conditions, though only agents' choices will determine which particular model from the subset consistent with these conditions will diffuse. ${ }^{98}$ Barnett deploys a very similar notion in reconciling cultural structures and actors' agency: "There has been relatively little consideration of where ... principled actors get their principles. Their identity, principles, and practices are not created from thin air but rather are shaped by their environment, an environment that contains various kinds of mechanisms that can and do force them to develop in ways that potentially increase their 'fitness' to survive in the environments they want to change." 99

\section{Facilitators}

If the concept of theorization depends on bounded agency to address the problem of underspecification, the exogenous structural change of the end of the Cold War is central in explaining the timing of norm emergence. As with many other constructivists, we see development as both a material and normative change. ${ }^{100}$ The end of the Cold War created two permissive conditions for the theorization process. First, it homogenized arguments emphasizing common problems and solutions. After 1989 formerly communist states and the organizations within them actively sought to adopt prevailing Western conceptions of the culture of modernity. ${ }^{101}$ Strang and Meyer specifically note how this change opened up fertile new ground for theorization: "When state socialism collapsed in Eastern Europe and the Soviet Union, Western academics rushed to the rescue, bearing analyses of optimal economic and political arrangements." 102 In concentrating on problems and solutions, the discussion of theorization has yet to deal with the construction of categories. During the Cold War both sides were shaped by the culture of modernity (for example, scientific

95. Barnett 2009, 631

96. Wendt 1999, 320.

97. Powell and DiMaggio 1991, 13.

98. Wendt 2003, 502. Also Barnett 2009.

99. Barnett 2009, 655-56.

100. See Katzenstein 1996; Wendt 1999; Bukovansky 2002; Reus-Smit 2011; and Sikkink 2011a.

101. Clark 2005.

102. Strang and Meyer 1993, 502. 
socialism), yet maintained different views on human rights and the proper relation between public and private economic activity and wealth. These differences made it difficult for actors to theorize that countries on different sides of this divide were experiencing essentially similar problems and therefore required generic solutions. By the early 1990s, however, formerly communist countries eagerly emulated Western models of human rights and economic governance. In doing so, they provided many opportunities for consultants, academics, international organizations, and NGOs to pitch their models of how these countries could meet prevailing modern standards of legitimacy.

Second, the end of the Cold War further exposed tensions within cultural tenets of modernity, such as sovereignty, human rights, individual responsibility, and rationalized authority. Structural changes are not simply an exogenous shock that opens up space for norms to emerge or expand; they innately contain a certain direction of change in their characteristics and carry important messages. The end of the Cold War was not simply a window of opportunity for any and every new norm, but strongly favored those compatible with underlying cultural tenets of human rights, individual responsibility, and the separation of public and private spheres in the economy. Thus Clark notes that since 1989 rightful membership of the international community has focused on conceptions of "human rights" and "good governance." 103 In light of the earlier critiques that structural accounts cannot explain the timing of change, it bears repeating that it was the changed structural conditions of the post-Cold War world that help explain when the new norms began to emerge.

Finally, once the specific nature and timing of norm emergence has been explained, how does this norm diffuse and become generally accepted? Here we return to the three mechanisms of mimetic isomorphism, professionalization, and coercive isomorphism. ${ }^{104}$ According to the first, organizations are likely to copy perceived innovators or leaders in a field to enhance their legitimacy when they face underspecified or unattainable goals. Professionalization refers to the formation of a group of experts who establish themselves as authorities thanks to their technical, specialized knowledge and/or scientific credentials. Like mimicry, sociological institutionalists see professionalization and norm diffusion as a simultaneous process in which each process advances the other. "These legitimated experts appeal to and further develop transnational accounts and models, yielding a self-reinforcing cycle in which rationalization further institutionalizes professional authority." 105 Coercive isomorphism is far removed from the coercion most International Relations scholars are familiar with, referring to peer review, benchmarking, and cultural expectations. ${ }^{106}$ 


\section{The Rise of Parallel Accountability Norms}

In this section we provide evidence to substantiate our claims about the structural conditions of probability, the process of theorization, the explanation of timing, and the mechanisms of generalized diffusion by tracing the rise of highly congruent norms of individual accountability for human rights and corruption crimes. The remaining sections give an empirical comparison between sociological institutionalist and agentic constructivist accounts. Key tenets of the culture of modernity represent the conditions of possibility. Actors exhibited agency, bounded and shaped by the common cultural milieu, in theorizing the specific norms mandating an international duty to hold individual leaders accountable. The outcome of theorization was contingent because other alternative formulations were possible. The exogenous structural change represented by the end of the Cold War was an important facilitating condition for this process of theorization which helps explain the timing of norm emergence. Finally, these norms have diffused globally through mimicry, professionalization, and coercive isomorphism.

We employ qualitative pattern-matching, ${ }^{107}$ following the method the relevant constructivists themselves tend to endorse and employ. ${ }^{108}$ This approach addresses explicit calls from constructivists for sociological institutionalists to bolster their cross-national analyses with case studies. ${ }^{109}$ Human rights norms should be an easy case for constructivism to explain, since many of their existing frameworks and concepts were derived from the case, whereas few constructivists have sought to explain the development of an anticorruption norm. Importantly, however, the close isomorphism between the two individual accountability norms, despite the near-complete separation of transnational actors promoting each cause, is a prima facie indication of the importance of background structural factors in explaining the rise and content of these norms. That two such similar norms should arise at the same time without conscious borrowing or cross-fertilization between the actors purportedly behind their rise strongly signals the primacy of contextual factors. ${ }^{110}$ Such background structural features tend to be obscured in case studies of one norm. It is less a case of agentic constructivist arguments being wrong than of them being incomplete. By zooming in and bracketing structure, agents' instrumental actions do indeed loom large as a proximate cause. But as Pierson, Wendt, Waltz, and sociological institutionalists have argued, this not only results in unanswered questions regarding a particular case (like the conditions of possibility), but also makes it much harder to discern recurrent patterns driven by structures. 


\section{Explaining the Content of Accountability Norms: The Culture of Modernity}

Rather than new policy problems of kleptocracy and state repression arising and then necessitating a new functional response, the international regime of individual accountability for corruption and human rights crimes reflects ideational and structural change, as long-standing practices came to be seen in a new way. Corrupt practices among senior public officials have probably been around as long as the idea that public money is separate from the ruler's personal wealth. Despite the rise of financial deregulation, technological advances, and talk of globalization more generally, there is little that is genuinely new about the rich and powerful hiding assets abroad. The same goes for those with power to engage in repression against their own populations-it is an old problem. Many more people were killed by their own governments in the twentieth century than the combat deaths of all the wars combined. ${ }^{111}$ New individual accountability norms are closely anchored in tenets of the culture of modernity. This culture was the font of these norms, which were instantiated as actors engaged in a process of adapting and elaborating extant themes. Furthermore, the actors who theorized these norms are constituted and bounded by this culture. ${ }^{112}$ The cultural structure long predates the particular NGOs and other actors involved in advancing the specific individual accountability norms.

At the heart of the anticorruption and human rights agenda are basic values that are key to the project of modernity. Prominent among them is the idea of rationalized impersonal authority. The most common definition of corruption is the abuse of public office for private gain. Though rarely elaborated, this definition clearly and directly grows out of the prior judgment that public and private spheres can and should be separated, and that functions of government should be exercised via impersonal authority. There is a presumption that the only appropriate way that governments should rule is in line with Weberian rational-legal authority, whereby authority inheres in the office, rather than the person occupying that role. According to this schema, public funds are properly separate and distinct from private monies; office holders should treat the funds and assets they control in their public capacity very differently from their private property.

The protection of basic human rights guaranteed in constitutions and law has been a critical element of rational-legal authority that is argued to trump particular local circumstances and mores. ${ }^{113}$ The culture of modernity mandates that the moral purpose of the state should be "the augmentation of individuals' purposes and potentialities," and that justice "must apply equally to all citizens, in all like cases." 114 Similarly, the modern notion of sovereignty is based on "the moral ideas ... about rights to worship, self-determination, racial equality, and human

111. Valentino estimates between 60 million to 150 million people were killed by mass killings compared with 34 million battle deaths during the same period. See Valentino 2004, 1.

112. See Barnett 2009, 621; and Meyer and Jepperson 2000.

113. Cole 2005, 473.

114. Reus-Smit 1999, 9, 129. 
rights." 115 Individuals become endowed with rights that must be respected in law, with a corresponding individual responsibility for transgressions that violate these rights. The criminalization of repression presupposes the separation of public and private spheres and further demonstrates that there should be a clear distinction between the appropriate exercise of public power and the abuse of it.

In accord with the prominence the world culture grants to human agency, it is unacceptable to maintain that corruption and human rights crimes are caused by structural factors that will be reduced only through the workings of long-term, impersonal mechanisms operating over decades, and thus that these issues are impervious to deliberate, calculated policy interventions. The idea of the policy problem that cannot at least potentially be addressed by such an intervention is almost unthinkable under the prevailing view that humans can reflexively create their social environment. As such, corrupt practices and mass human rights violations, especially by elites, are seen as a failings by responsible individuals that can and should be ameliorated if not eliminated by deliberate, calculated policy interventions, ${ }^{116}$ especially given the general cultural obligation to advance progressive goals via goal-directed instrumental action. ${ }^{117}$ The propinquity of the culture of modernity and the individual accountability norms is not only a reflection of these norms' derivation, but furthermore explains why they diffused so rapidly. Because the notion of the tipping point is underspecified in agentic constructivist accounts, there is little explanation of why audiences buy what norm entrepreneurs are selling. There is also little attention devoted to the source or derivation of their ideational wares. A sociological institutionalist perspective suggests these norms catch on because of their close fit with world culture, and more immediately because they present culturally approved solutions to culturally defined problems. Yet the culture of modernity is by itself incomplete as an explanation in two key respects: it is underspecified (why these particular norms?), and does not address the issue of timing (why these norms at this time?).

\section{Theorization: From the Culture of Modernity to New Norms}

New norms mandating individual accountability for corruption and human rights offenses were much more a product of the prior, deep-seated modernist worldview than a de novo creation of norm entrepreneurs or idiosyncratic responses to particular national circumstances. Yet the proximate process by which aspects of the cultural structure led to specific norms was one of problem definition and solution involving agency. In both the human rights and the corruption domain, the failure of some countries to converge on the basic modernist template of the ideal rational modern state came to be seen as problem caused by the purposive actions of autonomous, 
responsible individuals (especially leaders), which should be addressed by the same kind of action.

For each of the cases, the same basic framework of theorization applies. Actors began with a problem derived from the overarching cultural framework, which also created a responsibility to advance a solution. This process is often accelerated by exogenous shocks such as the end of the Cold War, which expose or highlight the problems. Agents then creatively drew upon broader cultural tropes to craft potential solutions. Although this process involved uncoordinated action by autonomous agents, there were pronounced similarities in the norms that resulted. These similarities not only were a product of the structurally derived menu of options from which actors chose, but also reflected the winnowing effect whereby norms that could be more closely anchored in fundamental cultural precepts were more likely to win acceptance. Thus although the resulting norms of individual accountability were the proximate result of actors' agency, this outcome was mainly shaped by the boundary conditions of the cultural structure.

In the case of corruption, by the end of the 1980s important sectors of the development community sought to discern why their nostrums had repeatedly failed to bear fruit in Africa. The diagnosis was that deviations from the rationalized principles of good governance, and specifically corruption, were to blame. ${ }^{118}$ From 1993 the NGO Transparency International effectively publicized this framing of the problem. The organization was founded by former World Bank officials who combined conventional commitments to development and rationalized governance in a relatively novel way that emphasized how corruption subverted good governance and therefore prevented development. Over the 1990s this theorization of corruption as a development problem was further specified to focus on leaders. ${ }^{119}$ Thus the NGO Global Witness, also founded in 1993, began with an interest in how illegal logging and "blood diamonds" funded conflict. By 1996 their reports focused on how these continuing crimes depended on corruption among ministers and heads of state. ${ }^{120}$ The early stages of this normative shift coincided with new instances of spectacular corruption resulting from the end of the Cold War, such as the hijacked privatization processes in Russia and other post-Communist states, which were perceived as potentially endangering the successful transition to market democracies. The declining political utility of thoroughly corrupt but reliably Western-oriented clients in the developing world (such as Mobutu Sese Seko in Zaire) in the post-Cold War environment meant that the kleptocratic foibles of these leaders received more official attention and public criticism.

The theorization of such leaders' culpability for grand corruption crimes is best spelled out in the United Nations/World Bank Stolen Assets Recovery (StAR) 
initiative. Though launched in 2007, this initiative reflected broad international agreement from several years prior. ${ }^{121}$ As the inaugural report revealingly puts it "the consensus was that StAR is an idea whose time has come." 122 It forcefully asserted that kleptocracy was the most damaging form of corruption, which had caused major development failures in the past and threatened the achievement of the Millennium Development Goals. ${ }^{123}$

Since the late 1990s separate transnational groups of lawyers, law enforcement professionals, and government officials had been reasoning through how best to fight kleptocracy. The solution was to make individual leaders accountable through attacking their foreign wealth, a step that was calculated to have been "the missing link" in earlier anticorruption efforts. ${ }^{124}$ Individual accountability was seen to constitute a solution to this problem by recovering assets for development, demonstrating accountability to victimized populations, and by deterring individual would-be kleptocrats. ${ }^{125}$ In 2004 Transparency International had released a report on corruption among political leaders that received a great deal of publicity. In particular the media and policy-makers focused especially on its list of the top ten individual kleptocrats of all time. ${ }^{126}$ Global Witness and the US Senate have been similarly successful in garnering policy and media attention with detailed reports built around lurid accounts of spectacular corruption by individual leaders. ${ }^{127}$ In 2003,111 countries had agreed to the UNCAC, chapter 5 of which is exclusively devoted to increasing individual accountability by facilitating international asset recovery.

The Marcos case marked the first large-scale return of stolen assets. In 1986 President Marcos of the Philippines was overthrown by a popular uprising, fleeing with his family to Hawaii, where he died in 1989. Such was his haste that a large amount of documentation was left behind suggesting the first family's role in stealing up to $\$ 10$ billion. Much of this wealth was held abroad, particularly in Switzerland and the United States. Human rights victims in the United States obtained a $\$ 2$ billion civil settlement against Marcos. Enforcing this claim depended on getting access to his offshore wealth. In 1991 the Philippines government lodged

121. Author's interview with United Nations Office on Drugs and Crime officials, Vienna, 17 September 2004; author's interview with World Bank, Washington, DC, 7 September 2004; author's interview with World Bank officials, Strasbourg, 22 February 2007; author's interview with OECD officials, Paris, 16 February 2007; author's interview with Commonwealth officials, London, 15 May 2007; author's interview with Global Witness officials, London, 18 May 2012; and author's interview with Transparency International officials, Berlin, 5 September 2011.

122. World Bank 2007, 3.

123. See World Bank 2007; and Asian Development Bank 2009.

124. World Bank 2007, 30.

125. See World Bank 2007; author's interview with Asian Development Bank officials, Strasbourg, 22 February 2007; author's interview with United Nations Office on Drugs and Crime officials, Vienna, 17 September 2004; author's interview with World Bank officials, Washington, DC, 7 September 2004; author's interview with Commonwealth officials, London, 15 May 2007, London; and author's interview with Global Witness officials, London, 7 September 2011.

126. Transparency International 2004.

127. See Global Witness 2009; and US Senate 1999. 
an application to seize money from Marcos-controlled bank accounts that had been frozen by emergency order of the Swiss government in April 1986, a case settled only in 2003 with the return of $\$ 656$ million.

Although this theorization of the problem and solution was highly consistent with the boundary conditions of the culture of modernity, it was by no means the only possibility. Transparency International's ranking of those states perceived as being the most to least corrupt suggests a model of holding whole countries accountable, rather than just individual leaders. ${ }^{128}$ Yet although intergovernmental bodies such as the G20 and others maintain formal country blacklists of tax havens and money-laundering jurisdictions, ${ }^{129}$ the idea of an equivalent corrupt countries list has not caught on. Establishing the individual guilt of corrupt leaders has been regarded as superior to collective punishment of whole countries, which affects both perpetrators and innocent victims alike. Another alternative (or complement) to the individual accountability norm is that of institutional design to minimize corruption risk. The OECD has done much low-profile work through its Public Management Service, but the results have not achieved the same normative or international legal impact. In this framing, bad institutions, not bad people, are at fault, and actors and individual responsibility recede into the background.

The human rights case also demonstrates that disparate actors responded to common problems with a similar solution. Cycles of civil conflicts and political instability in much of the developing world were regarded as another obstacle to progress. The United Nations and many NGOs working in the field concluded that an important way to break the cycle of conflict and instability was to address grievances relating to the perpetrators of mass human rights violations. ${ }^{130}$ The area of human rights has experienced a dramatic increase in legalization in the post-World War II period, starting from the 1948 Universal Declaration of Human Rights. States were expected to ratify human rights conventions and many governments regarded human rights treaties as a normative prescription constituting the legitimate identity of modern nation-states. ${ }^{131}$ It was a highly legalized issue area, but there were few tools to enforce the law. ${ }^{132}$

The tension between the legalized international model of human rights and the reality was graphically demonstrated by cases of genocide and mass atrocities such as those in Cambodia and Iraq. ${ }^{133}$ With the end of the Cold War, the international community again witnessed conspicuous failures of international human rights regimes, with the mass killings, genocide, and war crimes during conflicts in the former Yugoslavia, Rwanda, and West Africa. But the end of the Cold War also provided a "more permissive atmosphere for holding former repressive leaders of

128. Transparency International 2011.

129. Sharman 2011.

130. United Nations Security Council 2004, 2.

131. Meyer 1989.

132. Forsythe 2006, 93.

133. Power 2002. 
whatever ideological stripe accountable for past human rights violations." ${ }^{134}$ Beyond the ideational realm, the inability to play one superpower patron against another meant that many client states found themselves under increasing scrutiny for their human rights transgressions. International lawyers such as Cherif Bassiouni and Aryeh Neier, local journalists such as Mirko Klarin, and human rights NGOs such as Human Rights Watch, the Lawyers Committee for Human Rights, and Amnesty International started to see individual criminal sanctions "especially appropriate" as a means to hold accountable the perpetrators such as Slobodan Milosevic, Ratko Mladic, and Radovan Karadic. ${ }^{135}$

In May 1993, the UN Security Council unanimously endorsed the creation of the International Criminal Tribunal for the former Yugoslavia (ICTY). It was the first time that individuals who had committed war crimes, crimes against humanity, and genocide could be prosecuted in the international court. The solution of individual criminal accountability was again upheld by the UN Security Council's 1994 decision to create the similar international courts to prosecute individual perpetrators responsible for the Rwandan genocide. This new model was applied to the subset of civil and political rights, often referred to as rights to bodily integrity, especially the prohibition on torture, summary execution, disappearance, political imprisonment, and genocide, as well as for war crimes and crimes against humanity. The signing of the Rome Statue of the ICC in 1998 formalized and internationalized the individual criminal accountability norm for human rights violations. Various international human rights NGOs and sympathetic governments played a critical role. Most importantly, it was the Coalition for the International Criminal Court, encompassing 2,500 civil society organizations in more than 150 countries, that played a key role in the final stage. ${ }^{136}$

In each case, individual activists and human rights NGOs had an important role in theorizing individual accountability norms for human rights violations. However, similar to the corruption case, this theorization was one of many possibilities. In the realm of international human rights, a powerful alternative to individual accountability existed in the form of a state accountability model. The International Court of Justice, the UN Human Rights Committee, and the European Court of Human Rights focused on state legal accountability, where states, not individual leaders, were found in violation of their obligations and required to provide remedy. ${ }^{137}$ However, the state accountability model did not work in the face of mass atrocities such as genocides in Cambodia or Iraq, ${ }^{138}$ and similar to the corruption cases, the state accountability model was incomplete since individual state officials responsible for human rights violations

134. Sikkink 2011a, 246.

135. See Neier 2012, 264; Sikkink 2011a, 115; and Power 2002, 481. Power further finds that it was a local journalist, Mirko Klarin, who first urged the international prosecution for the perpetrators in the former Yugoslavia.

136. Sikkink 2011a, 118.

137. Kim and Sikkink 2010.

138. Power 2002, 124, 244. 
were still immune from prosecutions. ${ }^{139}$ Human rights violations seemed to be getting worse, and activists increasingly believed that only holding individuals accountable would provide a suitably strong incentive to change behavior. ${ }^{140}$

An important example of human rights and corruption accountability is the case of Augusto Pinochet. In 1998 Pinochet was arrested in Britain in line with a Spanish arrest warrant for the torture of Spanish citizens in Chile, which was invoked on the basis of universal jurisdiction for serious human rights offenses. Despite protests from the Chilean government, the British House of Lords overturned Pinochet's defense of sovereign immunity, ruling that serious human rights crimes invalidated such immunity, though the extradition attempt ultimately failed on health grounds. ${ }^{141}$ From 2000 Pinochet faced trial for human rights abuses in Chile, though again because of interruptions caused by his ill health, no convictions were obtained before his death in 2006. Meanwhile, in 1998 the Spanish government issued a worldwide attachment order seeking to freeze the assets of Pinochet and his family as part of their case, which led to Pinochet's Bermudan bank accounts being frozen. A highly critical US Senate report in 2004 charged that wealth Pinochet had hidden in the United States until 2002 was far in excess of his legitimate earnings, and noted widespread allegations of bribery and misappropriation of Chilean government funds. ${ }^{142}$ In response to criminal and civil legal action launched by the Spanish authorities against Pinochet's US bank (Riggs Bank) for complicity in hiding his wealth, an $\$ 8$ million penalty was used to compensate human rights victims of the Chilean military dictatorship. ${ }^{143}$ The week after the Senate report was released, the Chilean government charged Pinochet with bribery, embezzlement, and tax evasion, in addition to the human rights charges he was already facing.

In sum, disparate actors were frustrated by the disconnect between rationalized models of the modernist state, and conspicuous human rights and corruption failures. Actors exhibited agency in selecting and recombining elements drawn from the overarching cultural structure to theorize new diagnoses of problems and produce new specifications of individual criminal responsibility with which they hoped to address previously intractable problems. This process was contingent rather than deterministic, in that although boundary conditions favored some options over others, there were alternative paths that could have been followed.

\section{Norm Diffusion via Mimicry, Professionalization, and Coercive Isomorphism}

From the turn of the century, the diffusion of accountability norms was increasingly reflected in international treaties. In line with the sociological institutionalist logic of 
mimicry, states, international organizations and NGOs have copied perceived leaders in adopting standards to hold individual leaders accountable for human rights and corruption crimes. Those individuals with expertise in these fields have formed specialized communities looking to propagate and deepen the spread of these norms. A variety of formal and informal processes of review, evaluation, benchmarking, and best practice guides have reciprocally reinforced these developments to further advance norm diffusion and consolidation. In explaining this part of the diffusion process, agentic accounts either fall back on the undertheorized idea of the tipping point, or revert to sociological institutionalist concepts, despite the uncertain fit with much of the rest of their research program.

As a result of initiatives such as UNCAC and Stolen Assets Recovery, there are now a number of standardized guides to best practice in recovering dictators' loot, as well as technical assistance and capacity-building programs offered by an increasingly professionalized group of specialists in international organizations and NGOs such as the International Center for Asset Recovery. ${ }^{144}$ Once more, the generic rendering of the problem is that grand corruption is the single most damaging form of corruption, with the solution being to hold individual leaders accountable by targeting their illicit wealth. Assets recovered can be used to promote restorative justice, either through compensating victims of human rights abuses, or in repairing the economic damage done through the diversion of public funds. ${ }^{145}$

A parallel development occurred in the realm of human rights after the creation of the ICC. As more and more countries adopt individual accountability norms for human rights crimes, international organizations promote transitional justice as one of their policy goals. For example, new international NGOs such as the International Center for Transitional Justice have emerged, and many old NGOs such as Amnesty International and Human Rights Watch have included transitional justice in their main programs. Since 2004, the United Nations has officially incorporated transitional justice as a major policy tool to promote and protect human rights in conflict and postconflict societies. ${ }^{146}$

Finally, there is the idea of coercive isomorphism based on surveillance and benchmarking. The first UNCAC Conference of State Parties in 2006 instituted a peer review process to measure states' compliance. In 2010 the G20 announced an Anti-Corruption Action Plan with specific reference to the importance of corruption by senior officials and asset recovery. ${ }^{147}$ NGOs such as Transparency International and Global Witness energetically name and shame both corrupt leaders and those that host their wealth. ${ }^{148}$ On human rights accountability, international organizations such as the United Nations Office of the High Commissioner for Human Rights and

144. See, for example, Asian Development Bank 2006; World Bank 2007; and author's interview with International Centre for Asset Recovery officials, Basel, September 2010.

145. Carranza 2008.

146. United Nations Security Council 2004.

147. G20 2010.

148. Global Witness 2010. 
the United Nations Development Program, along with the ICC and donor states, have increasingly standardized practice, and press this accepted practice on countries in transition. Transitional justice has become something that is "normal, institutionalized, and mainstreamed," and transitioning states are now "expected, encouraged, or even coerced" to adopt transitional justice by "the international justice industry."149

\section{Conclusion}

Brutal and corrupt leaders increasingly run the risk of severe international legal consequences aimed at them as individuals for crimes they commit while in office. This development represents an important shift in world politics because of way these norms significantly limit the principle of sovereignty and sovereign immunity. Given the number of current state leaders guilty of human rights and corruption crimes, the further legalization of these norms looks likely to have enormous consequences for the conduct of diplomacy. Dominant International Relations theories have trouble explaining this shift. Realist and neoliberal accounts have difficulty explaining the cross-border diffusion of principled beliefs in the absence of utilitymaximizing or power-politics concerns, whereas these cases also reveal important shortcomings in recent agentic constructivist theory.

Drawing on the insights of sociological institutionalism, we have argued that the new norms of individual accountability are a product of quintessentially modernist conceptions of rationalized political authority and individual agency and responsibility. The definitive characterization of corruption-the abuse of public office for private gain - is directly derived from this modernist worldview. Likewise, protection of human rights guaranteed in constitutions and treaties has been a critical element of the Weberian notion of rational-legal authority and the primacy of the individual. The anticorruption and human rights movements were thus in large part a product of their intellectual and cultural environment. The process of norm emergence occurred thanks to disparate actors' theorizations-exercises of bounded agency shoved and shaped by structural boundary conditions. When individual norms are studied separately in a restricted time frame, scholars tend to give more attention to agency, and less to structure. However, by zooming out to examine longer-term developments and exploring the close similarities between these parallel norms of individual accountability, it is possible to provide a more comprehensive account.

One aspect of norm diffusion that both agentic and structural accounts have difficulty explaining is the rate of change. The norm life cycle advances an S-curve pattern of diffusion that begins slowly with early adopters, reaches a tipping point followed by a cascade, with the final hold-outs lagging the field. The slow-quick-slow rate of diffusion may be accurate in many cases, but it is more a description or hypothesis than an explanation as such. The question of the rate of diffusion is sometimes of 
little interest to structuralists. For example, Wendt argues, "like any structural tendency, the speed with which this one will be realized is historically contingent." 150 However, we still believe this is an important question and is a place where meaningful conversation between agentic and structural explanation can be taken in the future. Sociological institutionalists argue that theorization can affect the rate of diffusion. For example, Strang and Meyer see theorization as one of "the wider conditions under which expanded social relationships lead to rapid diffusion." 151 The diffusion process is accelerated by "culturally analyzed similarities among actors, and by theorized account of actors and practices." 152

Constructivism was in many ways founded on the basis of sociological institutionalism, and the two literatures still retain important similarities. Yet much recent constructivist work has sought to distance itself from important tenets of sociological institutionalism, especially by playing up the role of strategic agency. We believe that these innovations have caused the pendulum to swing too far away from structural concerns. If principled actors are creatures as well as creators of their world, our scholarship too seems to have been shaped by a culture privileging agency.

\section{References}

Abbot, Kenneth W., and Duncan Snidal. 2002. Values and Interests: International Legalization in the Fight Against Corruption. Journal of Legal Studies 31 (1):141-78.

Acharya, Amitav. 2004. How Ideas Spread: Whose Norms Matter? Norm Localization and Institutional Change in Asia Regionalism. International Organization 58 (2):239-75.

Adler, Emanuel. 2002. Constructivism and International Relations. In Handbook of International Relations, edited by Walter Carlsnaes, Thomas Risse, and Beth A. Simmons, 95-118. London: Sage. Adler, Emanuel, and Vincent Pouliot. 2011. International Practices. International Theory 3 (1):1-36.

Asian Development Bank. 2006. Denying Safe Haven to the Corrupt and the Proceeds of Corruption. Manila: Asian Development Bank.

Axelrod, Robert. 1984. The Evolution of Cooperation. New York: Basic Books.

Barnett, Michael. 2005. Social Constructivism. In The Globalization of World Politics: An Introduction to International Relations, edited by John Baylis, Steve Smith, and Patricia Owen, 160-73. Oxford, UK: Oxford University Press.

- 2009. Evolution Without Progress? Humanitarianism in a World of Hurt. International Organization 63 (4):621-63.

Barnett, Michael, and Martha Finnemore. 2004. Rules for the World: International Organizations in Global Politics. Ithaca, NY: Cornell University Press.

Bob, Clifford. 2002. Globalization and the Social Construction of Human Rights Campaigns. In Globalization and Human Rights, edited by Alison Brysk, 133-47. Berkeley: University of California Press.

Bukovansky, Mlada. 2002. Legitimacy and Power Politics: The American and French Revolutions in International Political Culture. Princeton, NJ: Princeton University Press.

150. Wendt 2003, 491.

151. Strang and Meyer 1993, 490.

152. Ibid., 487. 
2006. The Hollowness of Anti-Corruption Discourse. Review of International Political Economy 13 (2):181-209.

Carpenter, R. Charli. 2007. Setting the Advocacy Agenda: Theorizing Issue Emergence and Nonemergence in Transnational Advocacy Networks. International Studies Quarterly 51 (1):99-120.

Carranza, Ruben. 2008. Plunder and Pain: Should Transitional Justice Engage with Corruption and Economic Crimes? International Journal of Transitional Justice 2 (3):310-30.

Clark, Ann Marie. 2001. Diplomacy of Conscience: Amnesty International and Changing Human Rights Norms. Princeton, NJ: Princeton University Press.

Clark, Ian. 2005. Legitimacy in International Society. Oxford, UK: Oxford University Press.

. 2007. International Legitimacy and World Society. Oxford, UK: Oxford University Press.

Cole, Wade M. 2005. Sovereignty Relinquished? Explaining Commitment to the International Human Rights Covenants, 1966-1999. American Sociological Review 70 (3):472-95.

della Porta, Donatella, and Sidney Tarrow. 2012. Interactive Diffusion: The Coevolution of Police and Protest Behavior with an Application to Transnational Contention. Comparative Political Studies 45 (1):119-52.

de Sousa, Luis, Peter Larmour, and Barry Hindess, eds. 2009. Governments, NGOs and Anti-Corruption: The New Integrity Warriors. New York: Routledge.

Dobbin, Frank, Beth Simmons, and Geoffrey Garrett. 2007. The Global Diffusion of Public Policies: Social Construction, Coercion, Competition, or Learning? Annual Review of Sociology 33:449-72.

Doty, Roxanne Lynn. 1997. Aporia: A Critical Exploration of the Agent-Structure Problematique in International Relations Theory. European Journal of International Relations 3 (3):365-92.

Drori, Gili S., and Georg Krücken, eds. 2009. World Society: The Writings of John W. Meyer. Oxford, UK: Oxford University Press.

Drori, Gili S., John W. Meyer, and Hokyu Hwang, eds. 2006. Globalization and Organization: World Society and Organizational Change. Oxford, UK: Oxford University Press.

Finnemore, Martha. 1996. Norms, Culture, and World Politics: Insights from Sociology's Institutionalism. International Organization 50 (2):325-47.

Finnemore, Martha, and Kathryn Sikkink. 1998. International Norm Dynamics and Political Change. International Organization 52 (4):887-917.

- 2001. Taking Stock: The Constructivist Research Program in International Relations and Comparative Politics. Annual Review of Political Science 4:391-416.

Forsythe, David P. 2006. Human Rights in International Relations. 2nd ed. Cambridge, UK: Cambridge University Press.

George, Alexander L., and Andrew Bennett. 2005. Case Studies and Theory Development in the Social Sciences. Cambridge, MA: MIT Press.

Global Witness. 1996. Corruption, War and Forest Policy: The Unsustainable Exploitation of Cambodia's Forests. London: Global Witness. Available at <http://www.globalwitness.org/library/corruption-warand-forest-policy>. Accessed 1 September 2011.

Global Witness. 2009. Undue Diligence: How Banks Do Business with Corrupt Regimes. London: Global Witness.

Global Witness. 2010. "International Thief Thief": How British Banks Are Complicit in Nigerian Corruption. London: Global Witness.

Goddard, Stacie E. 2009. Brokering Change: Networks and Entrepreneurs in International Politics. International Theory 1 (2):249-81.

Group of Twenty (G20). 2010. G20 Agenda for Action on Combating Corruption, Promoting Market Integrity, and Supporting a Clean Business Environment. Toronto, Canada.

Hall, Peter A., and Rosemary C.R. Taylor. 1996. Political Science and the Three New Institutionalisms. Political Studies 44 (5):936-57.

Hawkins, Darren. 2004. Explaining Costly International Institutions: Persuasion and Enforceable Human Rights Norms. International Studies Quarterly 48 (4):779-804.

Hoffmann, Stanley. 1983. Reaching for the Most Difficult: Human Rights as a Foreign Policy Goal. Daedalus 112 (4):19-49. 
Huntington, Samuel P. 1987. Modernization and Corruption. In Political Corruption: A Handbook, edited by Arnold J. Heidenheimer, Michael Johnston, and Victor T. LeVine, 377-88. New Brunswick, NJ: Transaction.

Hurd, Ian. 2008. Constructivism. In The Oxford Handbook of International Relations, edited by Christian Reus-Smit and Duncan Snidal, 298-316. Oxford, UK: Oxford University Press.

Jackson, Patrick Thaddeus, and Daniel H. Nexon. 1999. Relations Before States: Substance, Process and the Study of World Politics. European Journal of International Relations 5 (3):291-332.

Katzenstein, Peter J., ed. 1996. The Culture of National Security: Norms and Identity in World Politics. New York: Columbia University Press.

2010. A World of Plural and Pluralist Civilizations: Multiple Actors, Traditions, and Practices. In Civilizations in World Politics: Plural and Pluralist Perspectives, edited by Peter J. Katzenstein, 1-40. New York: Routledge.

Keck, Margaret E., and Kathryn Sikkink. 1998. Activists Beyond Borders: Advocacy Networks in International Politics. Ithaca, NY: Cornell University Press.

Kelley, Judith. 2008. Assessing the Complex Evolution of Norms: The Rise of International Election Monitoring. International Organization 62 (2):221-55.

Kim, Hun Joon, and Kathryn Sikkink. 2010. Explaining the Deterrence Effect of Human Rights Prosecutions for Transitional Countries. International Studies Quarterly 54 (4):939-63.

Kissinger, Henry. 2001. The Pitfalls of Universal Jurisdiction. Foreign Affairs 80 (4):86-96.

Larmour, Peter. 2006. Civilizing Techniques: Transparency International and the Spread of AntiCorruption. In Global Standards of Market Civilization, edited by Brett Bowden and Leonard Seabrooke, 95-106. New York: Routledge.

Lutz, Ellen L., and Caitlin Reiger, eds. 2009. Prosecuting Heads of State. Cambridge, UK: Cambridge University Press.

March, James G., and Johan P. Olsen. 1989. Rediscovering Institutions: The Organizational Basis of Politics. New York: Free Press.

- 1998. The Institutional Dynamics of International Political Orders. International Organization 52 (4):943-69.

Mayntz, Renate. 2004. Mechanisms in the Analysis of Social Macro-Phenomena. Philosophy of the Social Sciences 34 (2):237-59.

McAdam, Douglas. 1982. Political Process and the Development of Black Insurgency 1930-1970. Chicago: University of Chicago Press.

McCoy, Jennifer L., and Heather Heckel. 2001. The Emergence of a Global Anti-Corruption Norm. International Politics 38 (1):65-90.

McEvoy, Kieran. 2008. Letting Go of Legalism: Developing a "Thicker" Version of Transitional Justice. In Transitional Justice from Below: Grassroots Activism and the Struggle for Change, edited by Kieran McEvoy and Lorna McGregor, 16-46. Oxford, UK: Hart Publishing.

Mearsheimer, John J. 1994/1995. The False Promise of International Institutions. International Security 19 (3):5-49.

Meyer, John W. 1989. Conceptions of Christendom: Notes on the Distinctiveness of the West. In Cross-National Research on Sociology, edited by Melvin Kohn, 395-413. Newbury Park, CA: Sage.

Meyer, John W., John Boli, George M. Thomas, and Francisco O. Ramirez. 1997. World Society and the Nation-State. American Journal of Sociology 103 (1):144-81.

Meyer, John W., and Ronald L. Jepperson. 2000. The "Actors" of Modern Society: The Cultural Construction of Social Agency. Sociological Theory 18 (1):100-20.

Meyer, John W., and Brian Rowan. 1977. Institutionalized Organizations: Formal Structure as Myth and Ceremony. American Journal of Sociology 83 (2):340-63.

Moravcsik, Andrew. 2000. The Origins of Human Rights Regimes: Democratic Delegation in Postwar Europe. International Organization 54 (2):217-52.

Neier, Aryeh. 2012. The International Human Rights Movement: A History. Princeton, NJ: Princeton University Press. 
Philpott, Daniel. 2001. Revolutions in Sovereignty: How Ideas Shaped Modern International Relations. Princeton, NJ: Princeton University Press.

Pierson, Paul. 2003. Big, Slow-Moving, and...Invisible: Macrosocial Processes in the Study of Comparative Politics. In Comparative Historical Analysis in the Social Science, edited by James Mahoney and Dietrich Rueschemeyer, 177-207. Cambridge, UK: Cambridge University Press.

Powell, Walter W., and Paul J. DiMaggio, eds. 1991. The New Institutionalism in Organizational Analysis. Chicago: University of Chicago Press.

Power, Samantha. 2002. A Problem from Hell: America and the Age of Genocide. New York: Basic Books. Price, Richard. 1998. Reversing the Gun Sight: Transnational Civil Society Targets Land Mines. International Organization 52 (3):613-44.

Reus-Smit, Christian. 1999. The Moral Purpose of the State: Culture, Social Identity, and Institutional Rationality in International Relations. Princeton, NJ: Princeton University Press.

- 2004. The Politics of International Law. In The Politics of International Law, edited by Christian Reus-Smit, 14-44. Cambridge, UK: Cambridge University Press.

- 2009. Constructivism. In Theories of International Relations, edited by Scott Burchill, Andrew Linklater, Richard Devetak, Jack Donnelly, Terry Nardin, Matthew Paterson, Christian Reus-Smit, and Jacqui True, 212-36. New York: Palgrave Macmillan.

. 2011. Struggles for Individual Rights and the Expansion of the International System. International Organization 65 (2):207-42.

Risse, Thomas, Stephen C. Ropp, and Kathryn Sikkink, eds. 1999. The Power of Human Rights: International Norms and Domestic Change. Cambridge, UK: Cambridge University Press.

Roht-Arriaza, Naomi. 2005. The Pinochet Effect: Transnational Justice in the Age of Human Rights. Philadelphia: University of Pennsylvania Press.

Schimmelfennig, Frank. 2001. The Community Trap: Liberal Norms, Rhetorical Action, and the Eastern Enlargement of the European Union. International Organization 55 (1):47-80.

Sharman, J.C. 2011. The Money Laundry: Regulating Criminal Finance in the Global Economy. Ithaca, NY: Cornell University Press.

Sikkink, Kathryn. 2011a. The Justice Cascade: How Human Rights Prosecutions Are Changing World Politics. New York: Norton.

- 2011b. "The Alchemy of Agency: How Constructivism Could Help Bridge the Gap Between IR Theory and Practice in World Politics." Keynote address, Millennium Annual Conference, London School of Economics, London, 22 October.

Simmons, Beth A. 2009. Mobilizing for Human Rights: International Law in Domestic Politics. New York: Cambridge University Press.

Strang, David, and John W. Meyer. 1993. Institutional Conditions for Diffusion. Theory and Society 22 (4): 487-511.

Subotic, Jelena. 2009. Hijacked Justice: Dealing with the Past in the Balkans. Ithaca, NY: Cornell University Press.

Suganami, Hidemi. 1999. Agents, Structures, Narratives. European Journal of International Relations $5(3): 365-86$.

Thomas, Daniel C. 2005. Human Rights Ideas, the Demise of Communism, and the End of the Cold War. Journal of Cold War Studies 7 (2):110-41.

Tolbert, Pamela S., and Lynne G. Zucker. 1996. The Institutionalization of Institutional Theory. In Handbook of Organization Studies, edited by Stewart R. Clegg, Cynthia Hardy, and Walter R. Nord, 175-90. London: Sage.

Transparency International. 2004. Global Corruption Report: Political Corruption. Berlin.

- 2011. Corruption Perceptions Index 2011. Berlin. Available at <http://cpi.transparency.org/ cpi2011/results/>. Accessed 12 September 2012.

United Nations Security Council. 2004. Report of the Secretary-General on the Rule of Law and Transitional Justice in Conflict and Post-Conflict Societies (S/2004/616).

US Senate. 1999. Permanent Subcommittee on Investigations. Private Banking and Money Laundering: A Case Study of Opportunities and Vulnerabilities. Washington, DC. 
2004. Money Laundering and Foreign Corruption: Enforcement and Effectiveness of the Patriot Act: Case Study of Riggs Bank. Washington, DC: Permanent Subcommittee on Investigations.

2005. Money Laundering and Foreign Corruption: Enforcement and Effectiveness of the Patriot Act: Supplemental Staff Report on US Accounts Used by Augusto Pinochet. Washington, DC: Permanent Subcommittee on Investigations.

Valentino, Benjamin A. 2004. Final Solutions: Mass Killing and Genocide in the Twentieth Century. Ithaca, NY: Cornell University Press.

Waltz, Kenneth N. 2000. Structural Realism After the Cold War. International Security 25 (1):5-41.

Weaver, Catherine E. 2008. Hypocrisy Trap: The World Bank and the Poverty of Reform. Princeton, NJ: Princeton University Press.

Wendt, Alexander. 1995. Constructing International Politics. International Security 20 (1):71-81. 1999. Social Theory of International Politics. Cambridge: Cambridge University Press.

2003. Why a World State Is Inevitable. European Journal of International Relations 9 (4):491542.

2005. Agency, Teleology and the World State: A Reply to Shannon. European Journal of International Relations 11 (4):589-98.

World Bank. 2007. Stolen Assets Recovery (StAR) Initiative. Challenges, Opportunities, and Action Plan. Washington, DC: World Bank/UN Office on Drugs and Crime. 